\title{
Soldiers with Stethoscope: the show must go on...
}

\author{
Jes Jose ${ }^{1, \odot}$ Ridhima Sharma ${ }^{2}$ Rohan Magoon ${ }^{3} \quad$ ItiShri $^{3}$
}

${ }^{1}$ Sri Jayadeva Institute of Cardiovascular Sciences and Research, Bengaluru, Karnataka, India

${ }^{2}$ Department of Paediatric Anaesthesia, Super Speciality Paediatric Hospital and Post Graduate Teaching Institute, Noida, Uttar Pradesh, India

${ }^{3}$ Department of Cardiac Anaesthesia, Atal Bihari Vajpayee Institute of Medical Sciences (ABVIMS) and Dr. Ram Manohar Lohia Hospital, Baba Kharak Singh Marg, New Delhi 110001, India52179180

J Card Crit Care 2021;5:179-180.

Ever since the World Health Organization (WHO) declared the Coronavirus disease 2019 (COVID-19) a pandemic, it continues to trouble the whole of humanity. ${ }^{1}$ The whole world finds itself in a state of despair and exhaustion of not only having to deal with the pandemic but also simultaneously addressing the fallout of social, political, and economic structure. The biggest brunt of this catastrophe called COVID-19 is being borne by the soldiers with stethoscopes-the medical fraternity-in every possible way.

We, as doctors, face unprecedented challenges in the form of a deadly masquerading enemy, which is highly infectious, has diverse signs and symptoms, mutates at the speed of light, and leads to everchanging consensus on the actual line of treatment and the unknown long-term ill effects. We have also faced long and exhausting working hours, insufficient resources, inefficient supply lines, especially with regard to drugs and equipment, including an oxygen crisis and multiple instances of violence against health care workers. ${ }^{2}$ Apart from the mental trauma of being an instrument of transmission, the virus affecting our near and dear ones, and staying away from our families, we have been repeatedly shocked at the news of the loss of our seniors and peers to this scourge.

According to the Indian Medical Association (IMA) COVID-19 registry, 864 doctors have already succumbed due to the pandemic in India, of which at least 420 doctors have lost their lives during the second COVID-19 wave. ${ }^{3}$ In a nation where doctor to population ratio remains low at 1:1456 against a WHO-recommended 1:1000, not only are we losing soldiers (doctors) fighting at the forefront but also feeling of a sense of anxiety, panic, and loss in terms of intellectual guidance. ${ }^{4}$ Amidst all the violence, mistrust, chaos, bombardment of nonscientific information, lack of standard guidelines, and reaching the brink of both physical as well as mental exhaustion, physicians are still attempting to find pearls in the mud. Short on supplies and sleep, we truly appreciate the nature of

published online

August 5, 2021
DOI https://doi.org/

$10.1055 / \mathrm{s}-0041-1732838$

ISSN 2457-0206
Address for correspondence Dr. ItiShri, MD, Department of Cardiac Anaesthesia, Atal Bihari Vajpayee Institute of Medical Sciences (ABVIMS) and Dr. Ram Manohar Lohia Hospital, Baba Kharak Singh Marg, New Delhi 110001, India (e-mail: iti.anesthesia@gmail.com).

our responsibility and duty toward our patients. ${ }^{5}$ We realize it is not just a mere professional doctor-patient relationship but a human bond.

Following the idea of complexity thinking, we acknowledge and accept the challenges as opportunities for positive adaptations, innovative solutions, and emerge as a stable system. ${ }^{6}$ Notwithstanding the crisis, we continue to be well-rooted in evidence-based medicine, continuous medical education programs through webinars, and training of juniors. We are keeping abreast of the everchanging treatment plans and strategies, and disseminating relevant medical information not just within the fraternity but also to the general public. So, by challenging uncertainty, embracing innovations, building resilience in character, and serving humanity, let us eulogize and immortalize this spirit of "the show must go on ..."

\section{Funding}

Support was provided solely from institutional and/or departmental sources.

\section{Conflict of Interests}

The authors declare no competing interests.

\section{References}

1 WHO Director-General's opening remarks at the media briefing on COVID-19 - 11 March 2020. Available at: https://www. who.int/director-general/speeches/detail/who-director-general-s-opening-remarks-at-the-media-briefing-on-covid-1911-march-2020. Accessed May 20, 2021

2 Health Care Workers are facing several challenges during COVID-19 pandemic: Dr. (Prof. Raju Vaishya). Available at: https://timesofindia.indiatimes.com/readersblog/newspost/health-care-workers-are-facing-several-challengesduring-covid-19-pandemic-dr-prof-raju-vaishya-11529/ Accessed May 26, 2020

(c) 2021. Official Publication of The Simulation Society (TSS), accredited by International Society of Cardiovascular Ultrasound (ISCU). This is an open access article published by Thieme under the terms of the Creative Commons Attribution-NonDerivative-NonCommercial-License, permitting copying and reproduction so long as the original work is given appropriate credit. Contents may not be used for commercial purposes, or adapted, remixed, transformed or built upon. (https://creativecommons.org/licenses/by-nc-nd/4.0/).

Thieme Medical and Scientific Publishers Pvt. Ltd. A-12, 2nd Floor, Sector 2, Noida-201301 UP, India 
3 Indian Medical Association (IMA) COVID Martyrs. Available at: https://www.ima-india.org/ima/. Accessed May 26, 2021

4 The doctor-population ratio in India is 1:1456 against WHO recommendation Samiksha Goel. Available at: https://www.deccanherald.com/business/budget-2020/ the-doctor-population-ratio-in-india-is-11456-againstwho-recommendation-800034.html. Accessed May 26, 2021
5 Magoon R, Kohli J, Kashav R, et al. Life post COVID-19: from infirmity to invictus. J Card Crit Care 2020;4:167-168

6 Khan S, Vandermorris A, Shepherd J, et al. Embracing uncertainty, managing complexity: applying complexity thinking principles to transformation efforts in healthcare systems. BMC Health Serv Res 2018;18(1):192 